\title{
The Effect of Debt Equity Ratio on Tax Planning Before and After Implementation of the Minister of Finance Regulation Number PMK-169/ PMK. 010/2015 on Registered Companies on the Indonesia Stock Exchange
}

\author{
Jumaily Pramajaya, Mohamad Adam, Marlina Widiyanti, Luk Luk Fuadah
}

\begin{abstract}
This study was conducted to analyze the effect of the debt-equity ratio (DER) on tax planning before and after the enactment of the Minister of Finance Regulation number PMK-169/PMK.010/2015. The data used in this study are financial reports submitted to the Indonesia Stock Exchange (IDX) for the period 2014-2017. Three hundred ninety companies were selected using a purposive sampling method with some requirements. The chosen samples are companies which have four finance reports in a row for the period, and those whose DER was more than zero (not negative) in 2014. The data used is cross-sectional panel data, using the data of liability and equity to measure capital structure, and earnings before tax (EBT) in which is the basis for imposing corporate income tax. The sample companies are divided into two groups to measure the impact of the regulation, namely groups of companies with DER above 4 and below 4. The results of the study show that the average DER of the company is 1.7 to 1.9 , which means that only a few companies have DERs above 4:1 as specified in PMK-169. Furthermore, based on the results of the study it is known that both group of companies with DER above and below 4, the company's DER does not affect EBT before and after the implementation of PMK-169.

The study implies that the application of PMK-169 by using a debt limitation rule is still not effective in minimizing potential tax loss due to debt interest expense of capital structure.
\end{abstract}

Index Terms: Capital Structure, DER, EBT, Tax Planning

Manuscript received on June 15, 2019

Revised Manuscript received on June 25, 2019.

Manuscript published on July 30, 2019.

* Correspondence Author

Jumaily Pramajaya*, S.E., Ak., Master of Management Candidate, Faculty of Economics, University of Sriwijaya, Palembang, Indonesia

Prof. Dr. Mohamad Adam, S.E., M.E., Lecturer, Faculty of Economics, University of Sriwijaya, Palembang, Indonesia

Hj. Marlina Widiyanti, S.E., S.H., M.M., Ph.D, Lecturer, Faculty of

Dr. Luk Luk Fuadah, S.E., M.B.A., Ak., Lecturer, Faculty of Economics, University of Sriwijaya, Palembang, Indonesia

(c) The Authors. Published by Blue Eyes Intelligence Engineering and Sciences Publication (BEIESP). This is an open access article under the CC BY-NC-ND license (http://creativecommons.org/licenses/by-nc-nd/4.0/) Economics, University of Sriwijaya, Palembang, Indonesia

\section{INTRODUCTION}

Companies have a goal to maximize shareholder welfare by maximizing the value of the company. Based on this goal, company managers perform functions of planning, organizing, directing, and supervising. Planning carried out by financial managers includes investment decisions, financing decisions, and asset management decisions (Fadah, 2013).One form of financial planning carried out by the company is tax planning. Taxes are compulsory levies based on the Acts (Article 1 of Law Number 28 of 2007). Tax is one of the most significant cash outlays in a company (Hillier, Ross, Westerfield, Jaffe \& Jordan, 2013. Article 29 of the corporate income tax, for example, takes $25 \%$ of net income (Article 17 of Law Number 36 of 2008). Taxes are divided into two types, namely direct and indirect taxes. Direct tax is a tax borne by the recipient of additional resources such as Income Tax (PPh), while in Value Added Tax (PPN), the tax is taken by the end consumer.

For companies, direct tax, or income tax is calculated as the company's operating expenses or costs that reduce profit margins. Reduced profits will reduce dividends received by shareholders and automatically affect the value of the company in society (Suandy, 2001). For this reason, managers try to maximize the accounting profits and minimize fiscal profits.

Tax planning activities are also included in financial management activities. But it should be noted that tax planning is different from the understanding of tax avoidance or tax evasion. Tax planning is carried out legally by taxpayers to lower tax burden exploiting loopholes in tax laws or regulations without violating the law. Managers try to minimize tax burdens as low as possible with proper methods, and by taxation provisions, with the ultimate goal of maximizing profits and ultimately increasing corporate value. Meanwhile, tax avoidance and tax evasion are unlawful and can be subject to legal sanctions criminal.

According to Crumbley D. Larry, Friedman Jack P., and Anders Susan B., in the Dictionary of Tax Term (Suandy, 2001), stated that:

"Tax planning is a systematic analysis of differing tax options aimed at minimizing the tax liability in current and future tax periods." 


\section{The Effect of Debt Equity Ratio on Tax Planning Before and After Implementation of the Minister of Finance Regulation Number PMK-169/ PMK. 010/2015 on Registered Companies on the Indonesia Stock Exchange}

The steps that applied to conduct tax planning against income tax payable is maximizing fiscal costs (deductible) and minimizing costs that cannot be deducted (non-deductible), including the selection of appropriate accounting methods.

As well as cash flow planning, financial managers also have investment management function such as capital budgeting, capital structure and working capital management (Hillier et al., 2013). Capital budgeting relates to long-term investment decisions made by the company, while, capital structure and working capital management are the efforts made by the company to obtain capital both for operating and investment activities for the company. This working capital can come from the acquisition of short or long-term debt or through the issuance of shares (Hillier et al., 2013).

In 1963, Modigliani and Miller developed the theory of capital structure and expanded it to income tax. The theory states that interest costs can save tax payments because interest can reduce taxable income (earning before tax/EBT) so that taxes paid by companies be lesser or tax deductible (Ross, Bianchi, Christensen, Drew, Westerfield \& Jordan, 2014). This theory is widely used in financial management literature and is one of the most popular methods used by company managers in determining capital structure policies.

Based on this theory, the company would prefer to invest on long-term debt to obtain a reduction in the tax burden by making the maximum loan interest possible. Although this theory was later challenged by some academics who stated that leverage is not a priority in corporate tax planning because the tax shield is not a dominant factor when companies plan capital structures (Tripathi and Kumar, 2013; Barakat and Rao, 2013; Widayanti, Triaryati, and Abundanti, 2016; Yuliandi, Mulyadi and Yusuf, 2016; Nasution, Siregar, and Panggabean, 2017; Wang, Guo, Ding, and Li, 2018), but some literatures support the Modigliani and Miller theory which states that companies try to plan taxes through capital structure (Noor, 2014; Lukiana, and Hartono, 2014; Khotimah, 2014; Koh, and Lee, 2014; Blouin, Huizinga, Leaven, and Nicodeme, 2014; Simamora, and Ryadi, 2015 ; Alipour, Mohammadi, and Derakhsan, 2015; Faccio and Xu, 2015; Sundari and Susilowibowo, 2016; Sorbe, Johansson, and Skeie, 2016; Salehi, Baharipour, and Mohammad, 2016; Alfandia, 2017; Ramadhan, Frandyanto, and Riandoko, 2017; Fonseca, Juca, Nakamura, and Santos, 2017; Rehman, Wang, and Mirza, 2017; Devereux, Maffini, and Xing, 2017).

With the tax on the company, the company with debt will be able to reduce the tax payment because the debt has interest costs, which will raise tax shields so that the company's value can increase. Thus the higher the company's debt, the value of the company will increase, or in other words, the company is encouraged to raise debt and their debt-equity ratio as a form of tax planning.

The potential tax loss derived from planned capital structure has been a concern of the Indonesian Government through the Directorate General of Taxes since 1984 with the issuance of the Minister of Finance Decree number 1002/KMK.04/1984 Comparison of Debt and Own Capital for Income Tax Imposition, which set the ratio of debt to equity at 3:1, but the law was later postponed in accordance with KMK-254/KMK.05/1985 concerning the Delay of Implementation of the Minister of Finance Decree Number 1002/KMK.04/1984 concerning Comparison Between Debt and Own Capital for Income Tax Imposition.
Only after 21 years later, the government issued a regulation governing the ratio of debt and capital (Debt to Equity Ratio), namely the Minister of Finance Regulation Number 169/PMK.010/2015 on 9 September 2015 about Determining the Amount of Comparison between Debt and Company Capital to Requirement for Income Tax Calculation.To measure the number of funds for investment by company owners in proportion to funds obtained from creditors, the company uses leverage ratios (Brealey, Myers, and Marcus, 1995, in Miswanto and Widodo, 1998). There are several leverage ratios used by companies, namely total debt to total capital asset ratio (debt ratio), total debt to equity ratio, long term debt to equity ratio, tangible debt coverage assets, times of interest coverage, debt service coverage and earnings variability. Of the several types of ratios, the debt to equity ratio (DER) is the most widely used.DER is a ratio to compare total debt with total owner's capital or equity (Miswanto and Widodo, 1998). This ratio is used to find out what part of each cent is from the owner's capital used to guarantee the debt. The greater the ratio, the more unprofitable for creditors because the amount of debt is greater than the owner's capital. This ratio serves to find out that every cent of its own capital is used as collateral for debt and there is no limit on the size of the ratio between the ratio of debt and capital (Statement of Financial Accounting Standards Number 26, 2011). DER is calculated by the formula:

Debt Equity Ratio = Total Debt / Owner's Capital

This thesis is a development of writing by Ramadhan, Frandyanto, and Riandoko (2017) who researched on the effect of the thin capitalization rule on company leverage in Indonesia. In the conclusion of the article it was stated that analysis should be carried out further by using more samples and more sophisticated methods. Therefore, this study will conduct research on the relationship between capital structure and tax planning before and after the enactment of government regulations using panel data regression method, a larger number of samples and in 4 (four) years (two years before and two years after).

\section{RESEARCH METHOD}

\section{A. Purpose of The Study}

This study analyzes the effectiveness of the impact of the application of the Minister of Finance Regulation number PMK-169/PMK.010/2015 on tax planning through capital structure conducted by companies listed on the Indonesia Stock Exchange for the period 2014-2017.

\section{B. Data Collection}

The study are using secondary quantitative data, namely data from financial statement submitted to the Indonesia Stock Exchange (IDX) and published through www.idx.co.id for the period 2014-2017. The data used is panel data cross-sectional, namely data collected by observing data and information on the same group of individuals (in this case the company) and observed from year to year (Hill, Griffiths, and Lim, 2008). The data observed are liability and equity to measure capital structure, and EBT, which is the basis for imposing a corporate income tax. 


\section{Population and Sample Size}

The population in this study are all companies which are listed on the Indonesia Stock Exchange for the period 2014-2017. The sampling method is non-probability purposive sampling technique, which is a sampling method based on specific considerations (Latan, 2014). This method selects samples because the researcher believes that the sample has met the requirements of the study, which is compatible with the characteristics of the study and meets the requirements for use as a sample.

From the total number of companies, the authors chose samples of companies that have financial reports for four consecutive years, namely 2014 to 2017 as many as 399 companies to maintain the consistency of company behavior towards capital structure and tax planning in each period. Next, from 399 companies, it is found that 9 companies had negative DER in 2014, so they should be eliminated. Therefore, the total sample becomes 390 subjects.

The 390 then divided into two groups, namely: companies; and

2) group of companies with DER below 4, that is 335 companies.

\section{Analysis Technique}

Analyzing data in this study will use the Stata application. Stata is one complete statistical program developed by StataCorp and widely used in the fields of economics and finance. Stata quickly analyze quantitative data in either cross-section, panel or time-series data.

The study on the influence of PMK-169/PMK.010/2015 on tax planning companies will use panel data regression methods. Panel data regression is a statistical model that combines cross-section data and time-series data so that the unit cross section (in this case the company's financial statement data) will be measured at different times (Hidayat, 2014). The panel data regression equation that will be used in this study is a two-way model that considers the effects of time or includes a time variable.

Hidayat (2014) states that the panel data regression method will give results that are best linear unbiased estimation (blue) if all Gauss Markov assumptions are met, one of which is non-autocorrelation.

The advantages of using panel data regression are as follows:

1) it can produce efficient econometric estimation because it provides the opportunity for researchers to use a large number of observations, improve the degree of freedom, data has a large variability and reduce the cholerearility between explanatory variables.

2) can provide information that cannot be provided by research using cross section data or time series data only.

3) can provide a better solution in dynamic change inference compared to cross-section data.

In the panel data regression model, the research is carried out by determining the estimation model. First, identifying the estimation model by using the common effect model or pooled least square (PLS), fixed effect model (FE), and random effect model (RE) approach. Second, to determine the right model between common effect (CE) and fixed effect (FE) using the Chow test, to choose the model between fixed effect and random effect using the Hausman test, and to determine the most appropriate model between random effects and the common effect with Lagrange Multiplier test.
1) group of companies with DER above 4, that is 55

Third, conducting an assumption test for data panel regression. In the pooled least square (PLS) and fixed effect model (FE) models, the assumption test is carried out by testing the linearity, normality, outlier, multicollinearity, heteroscedasticity, and autocorrelation tests. In the random effect model (RE) model, there is no need for heteroscedasticity and autocorrelation tests.

The tests will be conducted on both groups of the observation. The results of the statistical analysis above will then be elaborated with theories developed by taxation and accounting experts, especially those relating to the ratio of debt and capital.

\section{E. Dependent Variable (y)}

In this study, the authors will observe the tax planning behavior carried out by the company to decrease the amount of tax payable by using the tax shield scheme on capital structure. The tax planning will be proxied through the reported earnings before tax.

Earning before tax (EBT) - or in some literature referred to as income before tax - is the value of a company's revenue minus the cost of goods sold and other operating expenses before tax deductions (Sutton, 2004, p.49). EBT is the value of the company after operating and financing activities. Earning before tax $=$ Sales - Cost of good sold -

\section{Operational expense}

In fiscal finance, EBT is the basis for tax imposition before fiscal correction is carried out. So mainly, EBT can be used as a measure of the amount of corporate income tax that must be paid by the company. In the company's financial statements, the authors also found data of income tax reported by the company. However, based on the further examination on the notes of company's financial statements, income tax which is reported in the company's report is tax after adjusting for deferred tax, so that it cannot be used as a measurement of the value of taxes in the current year. Therefore, the authors determined to use EBT as the dependent variable.

\section{F. Independent variable $(x)$}

This study analyzed of the impact of the application of PMK-169 on tax planning through the capital structure. The company's capital structure consists of long-term debt and own equity so that the description of a company's capital structure can be proxied through a debt to equity ratio (DER).

Debt in this study is all the total company's debt cover long term, medium term, and short term. This is consistent with the definition of debt in article 1 paragraph (3) PMK-169, "the debt balance as referred to in paragraph (2) includes the balance of long-term debt and the balance of short-term debt including the balance of debt with interest."

Equity used in this study is all the total investment owned by the company, including those owned by minority parties (non-controlled interest). This is also in accordance with the understanding of capital in article 1 paragraph (5) PMK-169, "the capital balance referred to in paragraph (4) includes equity as referred to in the applicable financial accounting standards and interest-free loans from parties that have special relations."

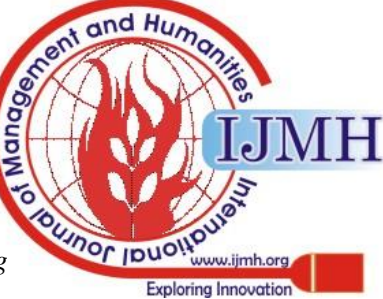


The Effect of Debt Equity Ratio on Tax Planning Before and After Implementation of the Minister of Finance

Regulation Number PMK-169/ PMK. 010/2015 on Registered Companies on the Indonesia Stock Exchange

Based on the research method, the hypothesis generated in the study is as follows:

$H_{1}$ : There is a significant effect of DER on tax planning before and after implementation of the Minister of Finance Regulation Number 169/PMK.10/2015 in the group of companies with DER above 4

$\mathrm{H}_{2}$ : There is a significant effect of DER on tax planning before and after implementation of the Minister of Finance Regulation Number 169/PMK.10/2015 in the group of companies with DER below 4

\section{FINDINGS AND DISCUSSION}

\section{A. Overview of Research Objects}

The research population is all companies listed on the Indonesia Stock Exchange in 2014-2017 from different sectors:

\section{Table 1. General Overview of Research Objects}

\begin{tabular}{r|rrr} 
sector & Freq. & Percent & Cum. \\
\hline agriculture & 18 & 4.62 & 4.62 \\
basic & 56 & 14.36 & 18.97 \\
consumer goods & 29 & 7.44 & 26.41 \\
finance & 71 & 18.21 & 44.62 \\
infrastructure & 3 & 0.77 & 45.38 \\
mining & 28 & 7.18 & 52.56 \\
miscellaneous & 27 & 6.92 & 59.49 \\
property & 49 & 12.56 & 72.05 \\
services & 36 & 9.23 & 81.28 \\
trade & 45 & 11.54 & 92.82 \\
utilities & 28 & 7.18 & 100.00 \\
\hline Total & 390 & 100.00 &
\end{tabular}

\section{B. Statistic Descriptive}

The results of the statistical description test in the Stata application show the results that the average DER of the company in the year before and after the enactment of PMK-169, is relatively fixed, ranging from 1.7 to 1.9. This average is far below the DER limit in accordance with the PMK, which is equal to 4:1.

Table 2. Statistic Descriptive of DER

\begin{tabular}{rlrcc}
\hline Year & Mean & Std. Dev. & Min & Max \\
\hline 2014 & 1.865593 & 2.352524 & 0.0002638 & 18.15169 \\
2015 & 1.774759 & 2.150293 & 0.0076258 & 13.33061 \\
2016 & 1.688463 & 2.25065 & -5.274194 & 16.81148 \\
2017 & 1.754461 & 2.545079 & -3.190476 & 30.4927 \\
\hline
\end{tabular}

Therefore, to obtain a comparison of the effectiveness of the implementation of PMK-390 samples are grouped into two, namely companies that have DERs above 4 and below 4 with reference years of 2014, in which year PMK-169 did not yet apply.

\section{Hypothesis Test Results on DER Group Above 4}

Determining Estimation Model
Based on the test results on the DER group above 4 (55 companies) to determine the estimation model, the following output is obtained:

Table 3. P-Value Output of Estimation Model

\begin{tabular}{lc}
\hline \multicolumn{1}{c}{ Estimation Model } & $\begin{array}{c}\text { P-Value } \\
\text { (Prob>F) }\end{array}$ \\
\hline Common Effect (CE) or Pooled Data & 0.5707 \\
Square (PLS) & \\
Fixed Effect Model (FE) & 0.0000 \\
Random Effect Model (RE) & 0.1808 \\
\hline
\end{tabular}

To compare the pooled data square (PLS) model with a fixed effect (FE) used Chow test. The hypothesis used in the Chow test is:

$\mathrm{H}_{0}$ : Pooled data square model

$\mathrm{H}_{1}$ : Fixed effect model

Based on the output of FE, the p-value (Prob $>\mathrm{F})=$ 0.0000 , the value is less than the alpha value of $5 \%(95 \%$ confidence level), then $\mathrm{H}_{0}$ is rejected, the model used is the fixed effect model (FE).

Hausman test is used to compare the fixed effect model (FE) with random effect (RE). The hypothesis used in the Hausman test is:

\section{$\mathrm{H}_{0}$ : Random effect model}

$\mathrm{H}_{1}$ : Fixed effect model

The Hausman test results show that the p-value (Prob > chi2) $=0.8846$, this value is greater than $5 \%$ so that $\mathrm{H}_{0}$ is accepted; the better model is the random effect (RE) model.

Since the model accepted is different from the results of the Chow test, the Lagrange Multiplier test is used to compare the PLS and RE models. The hypothesis used in the Lagrange Multiplier test is:

$H_{0}$ : Pooled data square model

$\mathrm{H}_{1}$ : Random effect model

The Lagrange Multiplier test output results with a p-value (Prob $>$ chibar2) $=0.0000$, this value is smaller than $5 \%$, so $\mathrm{H}_{0}$ is rejected, the random effect model is the best choice.

\section{Assumption Test}

Based on the Shapiro Wilk normality test using Stata shows that, the $\mathrm{p}$-value (Prob $>\mathrm{z}$ ) $=0.0000$, which indicates that the data is not normally distributed. But considering the data used is secondary and utilized the data panel method, normality is not a major factor in determining assumption tests (Iqbal, 2015). Test assumptions used in panel data regression are multicollinearity, heteroscedasticity, and autocorrelation (Satria, 2018).

Based on the multicollinearity assumption of panel data regression over the group of companies with DER above 4, the output value of the Variance Inflating Factor (VIF) $=1$ is obtained. Given that the independent variable in the study was only one (DER), the tolerance value or VIF $=1$, which indicates that there are no symptoms of high multicollinearity so that the model and hypothesis used are acceptable and the level of parameter confidence is getting better. 
Table 4. Output of Autocorrelation Test

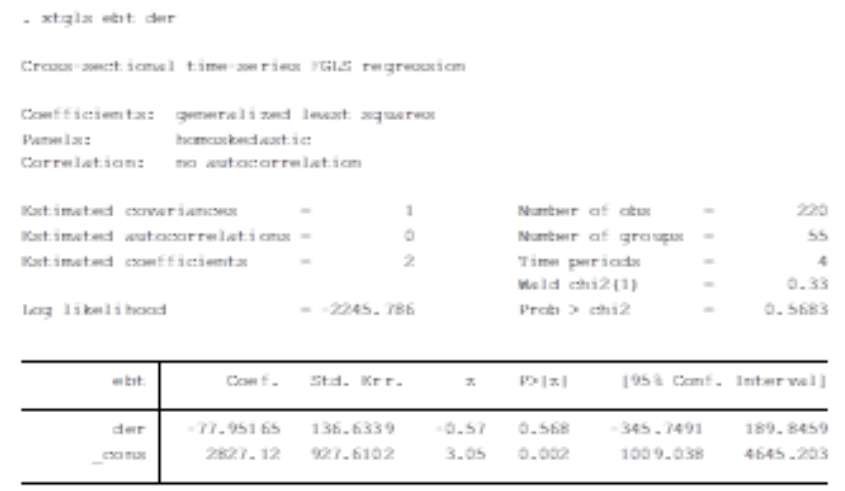

Both heterocedasticity test and autocorrelation in the random effect model used generalized least square (GLS), so it only needs to be done once. Heterocedasticity test results have an output $\mathrm{P}$-value $($ Prob $>$ Chi2 $)=0.5683$. These results indicate there is no autocorrelation between one observation and other observations so that the possibility of errors in the model does not occur. The Gauss Markov assumption is fulfilled (non-autocorrelation) so that the model can provide

\section{Interpretation of Results}

Based on the steps to determine the estimation model and assumption test, it can be concluded that panel data regression to test the effect of DER on EBT in the group of companies with DER above 4, can be done using the random effect (RE) model. The results of panel data regression testing with the random effect (RE) model provide output p-value (Prob $>$ chi2) $=0.1808>0.05$ (with a 95\% confidence level) so that $\mathrm{H}_{0}$ is accepted, DER does not affect EBT on companies listed in the IDX before and after the application of PMK-169 with DER above 4.

\section{Hypothesis Test Results on DER Group Below 4}

\section{Determining Estimation Model}

Subsequent research was conducted on companies that have DERs below 4, namely 335 companies. Based on the test results determining the estimation model, the following output is obtained:

\section{Table 5. P-Value Output of Estimation Model}

\begin{tabular}{lc}
\hline \multicolumn{1}{c}{ Estimation Model } & $\begin{array}{c}\text { P-Value } \\
\text { (Prob }>\text { F) }\end{array}$ \\
\hline $\begin{array}{l}\text { Common Effect atau Pooled Data Square } \\
\text { (PLS) }\end{array}$ & 0.0391 \\
Fixed Effect Model (FE) & \\
Random Effect Model (RE) & 0.0000 \\
\hline
\end{tabular}

Chow test is used to compare pooled data square (PLS) models with fixed effects (FE). As before, the hypothesis used in the Chow test is:

$\mathrm{H}_{0}$ : Pooled data square model

$\mathrm{H}_{1}$ : Fixed effect model

Based on the output of FE in the group of companies with DER below 4, the p-value (Prob $>F)=0.0000$, so that it is less than the value of $5 \%$ (95\% confidence level), then $\mathrm{H}_{0}$ is rejected, the model is used is a fixed effect model (FE). results that are best linear unbiased estimation (blue).

To compare the fixed effect model (FE) with random effect (RE), Hausman test is used. The hypothesis used in the Hausman test is:

\section{$\mathrm{H}_{0}$ : Random effect model}

$\mathrm{H}_{1}$ : Fixed effect model

The Hausman test results show that the p-value (Prob > chi2) $=0.5054$, this value is greater than $5 \%$ so that $\mathrm{H}_{0}$ is accepted, the better model is the random effect (RE) model.

The third test used the Lagrange Multiplier test to compare PLS and RE models. The hypothesis used in the Chow test is:

\section{$H_{0}$ : Pooled data square model}

$\mathrm{H}_{1}$ : Random effect model

The Lagrange Multiplier test output results with a p-value (Prob $>$ chibar2) $=0.0000$, this value is smaller than alpha (5\%), so $\mathrm{H}_{0}$ is rejected, the RE model is better than PLS.

\section{Assumption Test}

The results of the Shapiro Wilk normality test using Stata show that the Prob value $>\mathrm{z}=0.0000$, indicating the data is not normally distributed. Therefore, research uses multicollinearity, heteroscedasticity, and autocorrelation tests. The multicollinearity assumption results of panel data regression for the group of companies with DER below 4 indicate VIF $=1$, which shows that there are no symptoms of high multicollinearity so that the model and hypothesis used can be accepted and the level of confidence in the parameters is good.

Table 6. Output of Autocorrelation Test

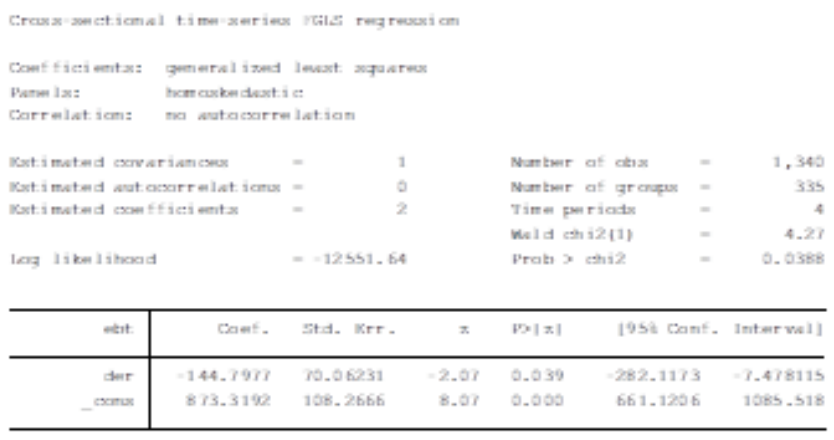

Heterocedasticity test results have P-Value output (Prob > chi2) $=0.0388$. These results indicate there is no autocorrelation (no autocorrelation) between one observation and other observations so that the possibility of errors in the model does not occur because it provides results that are best linear unbiased estimation (blue).

\section{Interpretation of Results}

Based on the tests, it can be concluded that panel data regression to test the effect of DER on EBT in the group of companies with DER below 4, can be done using the random effect (RE) model. The results of panel data regression with the random effect (RE) model give the output of p-value $($ Prob $>$ Chi2) $=0.0685>0.05$ (with 95\% confidence level) so that $\mathrm{H}_{0}$ is accepted, there is no DER effect on EBT in the company listed on the IDX before and after the application of PMK-169 in the group of companies with DER below 4. 


\section{The Effect of Debt Equity Ratio on Tax Planning Before and After Implementation of the Minister of Finance Regulation Number PMK-169/ PMK. 010/2015 on Registered Companies on the Indonesia Stock Exchange}

\section{Discussion of Problems}

Based on the results of statistical description tests conducted on 390 companies listed on the Indonesia Stock Exchange in 2014 to 2017, data obtained shows that the average DER of companies was 1.7 to 1.9 which means that only a few companies have DERs above 4: 1 . Based on these results, the researchers concluded that the DER limits applied in PMK-169 were still too high to be able to effectively reduce the company's tax planning through charging interest on loans.

Furthermore, based on the examination results, it is concluded that in the group of companies with DER above 4 and below 4, the company's DER does not affect EBT before and after the implementation of PMK-169. This result is different from the results of research conducted by Ramadhan, Frandyanto and Riandoko (2017) which states that the thin capitalization rule can provide significant changes to the debt to equity ratio of Indonesian Stock Exchange Companies in group 1 (Debt to Equity Ratio of more than 4:1) and group 2 (Debt to Equity Ratio less than $4: 1)$.

Based on Modigliani and Miller's theory, the company would prefer to invest by using long-term debt to obtain a reduction in the tax burden by making the maximum loan interest possible. Thus, the loan interest rate is the most certain thing in carrying out tax planning through charging interest, therefore debt limitation as applied in PMK-169 becomes inappropriate. According to Darussalam and Kristiaji (2015), the debt limitation policy is actually less effective compared to the effort to limit interest expenses (interest limitation). The interest expense limitation policy is a direct approach based on information originating from the income statement so that it is more precise and effective, but unfortunately, only a few countries apply the policy.

In various countries, the policy of using DER as a tool for limiting interest expense has begun to be evaluated and replaced by other policy alternatives such as Allowance for Corporate Equity (ACE) and Comprehensive Business Income Tax (CBIT) (Mirrlees, Adam, Besley, Blundell, Bond, Chote, Gammie, Johnson, Myles, and Poterba, 2011).

Darussalam and Kristiaji (2015) also suggested that the application of DER restrictions, although easier to implement administratively, was less effective because it was arbitrary, subjective and did not take into account market conditions such as the type of industrial sector or business development phase. For developing countries like Indonesia, the use of interest limitation rules will be more optimal in limiting the use of debt borrowing costs to reduce the tax burden to reduce tax avoidance by the company.

\section{CONCLUSIONS}

This study analyzes the effect of the DER on the company's tax planning in the period before and after the enactment of PMK-169/PMK.010/2015 in groups of companies that have DERs above and below 4. Based on the research and analysis, the results show as follows:

1) the average DER of the company in the year before and after the enactment of PMK-169 is a relatively fixed between 1.7 - 1.9. This average is far below the DER limit in accordance with the PMK which is equal to $4: 1$;

2) in the group of companies with DER above 4, DER does not affect EBT for companies listed on the IDX before and after the application of PMK-169.
3) in the group of companies with DER below 4, DER also does not affect EBT for companies listed on the IDX before and after the application of PMK-169.

Based on the conclusions above, the researcher gives suggestions as follows:

1) for the Directorate General of Taxes, it is recommended to carry out further evaluations on the effectiveness of the impact of the application of PMK-169 by limiting to reduce corporate tax planning, for example by conducting internal studies using confidential annual tax return data. The Directorate General of Taxes can also conduct a more in-depth research of the possible changes in the policy model of the debt limitation rule with other policies such as the interest limitation rule, Allowance for Corporate Equity (ACE) and Comprehensive Business Income Tax (CBIT);

2) for practitioners and tax academics, to make further studies regarding the method of limiting tax planning through capital structure.

3) for the next researchers, to make more in-depth and detail studies, especially on long-term loan interest, using a more comprehensive research method such as the difference in difference method over a more extended period.

\section{REFERENCES}

1. Fadah, I. 2013. Manajemen Keuangan (Suatu Konsep Dasar). Jember: Universitas Jember.

2. Law of the Republic of Indonesia Number 28 of 2007 concerning Fourth Amendment to Law Number 6 of 1983 concerning General Provisions and Procedures for Taxation

3. Hillier D., Ross S., Westerfield R., Jaffe J., \& Jordan B. 2013. Corporate Finance. NSW: McGraw Hill.

4. Law of the Republic of Indonesia Number 36 of 2008 concerning Fourth Amendment to Law Number 7 of 1983 concerning Income Tax.

5. Suandy E. (2001). Perencanaan Pajak. Jakarta: Salemba Empat.

6. Ross, S., Bianchi, R., Christensen, M., Drew, M., Westerfield, R., dan Jordan, B. 2014. Fundamentals of Corporate Finance, NSW: McGraw Hill Education.

7. Tripathi V., \& Kumar L. 2013. Corporate Financing \& Taxation: A Dynamic Panel Data Modelling. International Journal of Financial Management. 4(1). 23-34.

8. Barakat, M., \& Rao, R.P. 2013. The Role of Taxes in Capital Structure: Evidence from Taxed and Non-Taxed Arab Economies. MPRA Paper No. 25472

9. Widayanti, L.P., Triaryati, N. \& Abundanti, N. 2016. Pengaruh Profitabilitas, Tingkat Pertumbuhan Perusahaan, Likuiditas dan Pajak Terhadap Struktur Modal pada Sektor Pariwisata. E-Jurnal Manajemen Unud. 5(6). 3761-3793.

10. Yuliandi, Mulyadi, J.M.V. \& Yusuf M. 2014. Pengaruh Profitabilitas, Tangibilitas, Risiko Bisnis, Pajak, Non Debt Tax Shield terhadap Struktur Modal Serta Implikasinya terhadap Nilai Perusahaan. Jurnal Riset Akuntansi dan Perpajakan. 3(2). 251-263.

11. Nasution, A.A., Siregar, I., \& Panggabean, R. 2017. The Effect of Profitability, Asset Tangibility, Corporate Tax, Non-Debt Tax Shield and Inflation upon the Financial Capital Structure of the Manufacturing Companies Listed on The Indonesian Stock Exchange. Advance in Economics, Business and Management. 65-74.

12. Wang, P., Guo, K., Ding, D., \& Li, S. 2018. Property Rights, Tax Avoidance and Capital Structure: Data from China Stock Markets. International Journal of Economics and Finance. 10(11). 13-27.

13. Noor, A. 2016. Debt to Equity Rule: Thin Capitalization dalam Perkembangan Investasi di Indonesia. Jurnal Penelitian Hukum. 1(3). 143-153. 
14. Lukiana, N. \& Hartono. 2014. Struktur Modal Dipengaruhi oleh Beban Pajak, Risiko Bisnis, dan Struktur Kepemilikan (Studi Pada Perusahaan Manufaktur yang Listed di Bursa Efek Indonesia Periode 2009-2012). Jurnal WIGA. 4(2). 28-38.

15. Khotimah, H. 2014. Pengaruh Perencanaan Pajak Terhadap Manajemen Laba. Jurnal Bisnis dan Manajemen. 4(2). 170-177.

16. Koh, Y. \& Lee, H.A. 2014. The Effect of Financial Factors on Firms' Financial and Tax Reporting Decision. Journal of Emerald. 23(2). 110-138.

17. Blouin, J., Huizinga, H., Leaven, L., \& Nicodeme, G. 2014. Thin Capitalization Rule and Multinational Firm Capital Structure. IMF Working Paper. 1-37.

18. Simamora, P., \& Ryadi, MRM. 2015. Pengaruh Struktur Modal Terhadap PPh Badan Terutang Terhadap Perusahaan Manufaktur Sektor Industri Semen Yang Terdaftar Di BEI Periode Tahun 2010-2013. Jurnal Ilmiah Akuntansi Fakultas Ekonomi. 1(2). 21-31.

19. Alipour, M., Mohammadi, M.F.S., \& Derakhsan, H. 2015. Determinants of Capital Structure: An Empirical Study of Firms in Iran. International Journal of Law and Management. 57(1). 53-83.

20. Faccio, M., \& Xu, J. 2015. Taxes and Capital Structure. Journal of Financial and Quantitative Analysis. 50(3). 277-300.

21. Sundari, D., \& Susilowibowo J. 2016. Pengaruh Ukuran Perusahaan dan Non-Debt Tax Shield Terhadap Struktur Modal pada Perusahaan Sektor Keuangan. Jurnal Ilmu Manajemen. 1-12.

22. Sorbe, S., Johansson A., \& Skeie O.B. 2016. Debt and Tax Planning by Multinationals. Economics Departments Working Paper No.1357. 1-27.

23. Salehi, A.K., Baharipour, A., \& Mohammad, S. 2016. The Impact of Institutional Ownership on The Relationship Between Tax and Capital Structure. Advances in Mathematical Finance and Application. 1(2). 57-67.

24. Alfandia, N.S. 2017. Pajak dan Struktur Modal Perusahaan Manufaktur di Indonesia. Berkala Akuntansi dan Keuangan Indonesia. 3(1). 17-34.

25. Ramadhan, M.R., Frandyanto, S.A., \& Riandoko, R. 2017. Pengaruh Thin Capitalization Rule pada Leverage Perusahaan di Indonesia: Studi Perbandingan antara Perusahaan yang Memiliki Debt to Equity Ratio lebih dari 4:1 dan kurang dari 4:1. Conference Paper, July. ISSN-2252-3936.

26. Fonseca, P.V.D., Juca, M.N., Nakamura, W.T., \& Santos, J.O.D. 2017. The Influence of Debt Tax Benefit in the Capital Structure. GAI International Academic Conferences Proceedings. June 11-13. New York, United States.

27. Rehman, A., Wang, M., \& Mirza, S.S. 2017. How do Chinese Firms Adjust Their Financial Leverage: An Empirical Investigation Using Multiple GMM Models. China Finance and Economic Review. 5(8). $1-30$.

28. Devereux, M., Maffini, G., \& Xing, J. 2017. Corporate Tax Incentives and Capital Structure: New Evidence from UK Firm-Level Tax Returns. Working Paper. 17/19. Oxford University: Center for Business Taxation.

29. Miswanto, \& Widodo, E. 1998. Manajemen Keuangan I, Jakarta: Gunadarma.

30. Statement of Financial Accounting Standards Number 26. 2011. concerning Loan Costs. Indonesian Institute of Accountants, Jakarta.

31. Hill, R.C., Griffiths, W.E., \& Lim, G.C. 2008. Principles of Econometrics. Third Edition. USA: Wiley.

32. Latan, H. 2014. Aplikasi Analisis Data Statistik untuk Ilmu Sosia Sains dengan STATA. Bandung: Penerbit Alfabeta.

33. Hidayat A. 2014. Penjelasan Metode Analisis Regresi Data Panel. www.statistikian.com. Accessed on 2 April 2019. <https://www.statistikian.com/2014/11/regresi-data-panel.html>

34. Sutton, T. 2004. Corporate Financial Accounting and Reporting. Second Edition. England: Pearson Education Limited.

35. Iqbal, M. 2015. Regresi Data Panel (2) "Tahap Analisis". Dosen.perbanas.id. 20 January. Accessed on 19 Juny 2019. <https://dosen.perbanas.id/regresi-data-panel-2-tahap-analisis/>

36. Satria, D. 2018. Panel Data with Stata. Researchgate.net. Accessed on 19 Juny 2019. $<$ https://www.researchgate.net/publication/326394644__ Modul_ panel_data_dengan_menggunakan_STATA>

37. Darussalam, \& Kristiaji, B.B. 2015. Telaah Konstruktif Debt to Equity Ratio di Indonesia. Iaiglobal.or.id. Accessed on 10 October 2018. $<$ http://www.iaiglobal.or.id/v03/files/file_publikasi/>

38. Mirrlees, J., Adam, S., Besley, T., Blundell, R., Bond, S., Chote, R., Gammie, M., Johnson, P., Myles, G., \& Poterba, J. (2011). Tax By Design: The Mirrlees Review. UK: Oxford University Press.

\section{AUTHORS PROFILE}

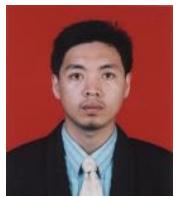

Jumaily Pramajaya, S.E., Ak., Corresponding Author, Master of Management Candidate, Faculty of Economics, University of Sriwijaya, Palembang, South Sumatera, Indonesia, jumaily.pramajaya@gmail.com, $+628127831202$

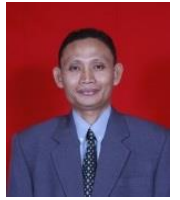

Prof. Dr. Mohamad Adam, S.E., M.E., Financial Management Expert, Vice Dean for Academic Fairs, Lecturer, Faculty of Economics, University of Sriwijaya, Palembang, South Sumatera, Indonesia

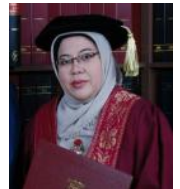

Hj. Marlina Widiyanti, S.E., S.H., M.M., Ph.D, Financial Management Expert, Head of Magister of Management Program, Lecturer, Faculty of Economics, University of Sriwijaya, Palembang, South Sumatera, Indonesia

Dr. Luk Luk Fuadah, S.E., M.B.A., Ak., Accounting Expert, Head of Professional Accounting Education Program, Lecturer, Faculty of Economics, University of Sriwijaya, Palembang, South Sumatera, Indonesia 